\title{
Local and international celebrity endorsers' credibility and consumer purchase intentions
}

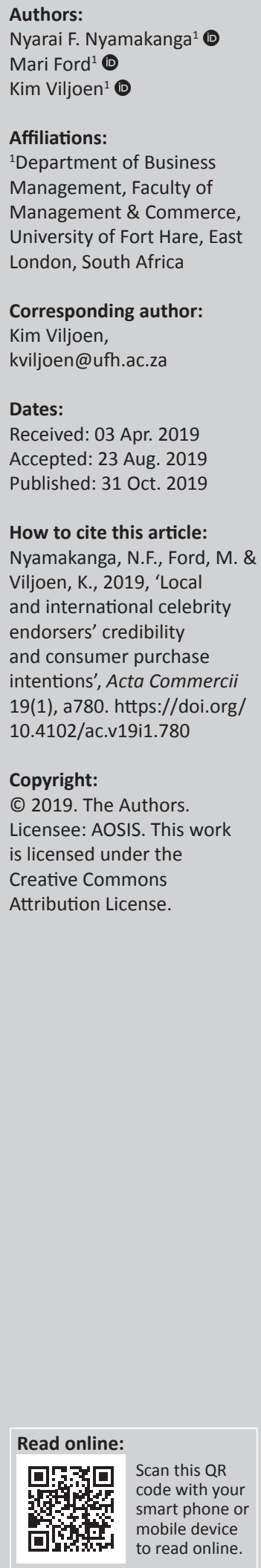

Authors:

Mari Ford ${ }^{1}$

Kim Viljoen ${ }^{1}$

Affiliations:

${ }^{1}$ Department of Business

University of Fort Hare, East

don, South Africa

Kim Viljoen,

Dates:

Received: 03 Apr. 2019

Accepted: 23 Aug. 2019

Viljoen, K., 2019, 'Local

and international celebrity

intentions', Acta Commercii

19(1), a780. https://doi.org/

Copyright:

Licensee: AOSIS. This work

is licensed under the

Creative Commons
Orientation: Marketers are under increasing pressure to improve their brand equity, product sales and market share. Celebrity endorsement has been shown to impact all of these positively and is a highly effective tool for influencing consumer behaviour.

Research purpose: The purpose of this study was to compare how the credibility of local and international celebrities influences female generation $\mathrm{Y}$ and $\mathrm{Z}$ consumers to purchase the cosmetic products they endorse.

Motivation for the study: Marketing managers allocate large portions of their budget towards celebrity endorsement, without fully understanding how local and international celebrities' credibility might differ in terms of their influence on consumer behaviour.

Research design, approach and method: Self-administered questionnaires were distributed to generation $\mathrm{Y}$ and $\mathrm{Z}$ female consumers using the non-probability convenience sampling method and the final sample contained 237 usable questionnaires. Multiple regression was conducted using SPSS version 24 in order to test the hypotheses.

Main finding: Results showed that it was the attractiveness and trustworthiness of local celebrities that had a significant effect on generation $\mathrm{Y}$ and $\mathrm{Z}$ consumers' purchase intentions, while it was the expertise of international celebrities that significantly influenced purchase intentions.

Practical/managerial implications: Marketing executives should consider using local and international celebrities for different purposes in their brand advertising.

Contribution/value-add: The study suggests that the celebrity's nationality may be a moderating variable in terms of how they influence consumer behaviour.

Keywords: celebrity credibility; celebrity endorsements; cosmetic products; generation Y \& Z; purchase intentions.

\section{Introduction}

The use of celebrities to endorse products and brands in advertising began as early as the 18th century (Winterich, Gangwar \& Grewal 2018). Since then, it has become a widely used advertising technique and has also been widely researched. A celebrity endorser is defined as 'any individual who enjoys public recognition and uses this recognition on behalf of a consumer good by appearing with it in an advertisement' (McCracken 1989:310). Previous studies have shown that celebrity endorsement can be very beneficial to businesses, by increasing brand recognition, brand recall and brand awareness, as well as increasing sales, profits and even market share (Bergkvist \& Zhou 2016; Knoll \& Matthes 2017). Not surprisingly, celebrity endorsement has increased globally in recent years, especially in relation to the advancement of marketing in the digital environment and the emergence of social networking sites like Instagram. Instagram, in particular, has extended the idea of celebrity to include micro-celebrities who are ordinary people who become famous by appearing regularly on social media and endorse products and brands on those platforms (Jargalsaikhan \& Korotina 2016; Moraes et al. 2019). Varying statistics from western countries show that, in general, up to $25 \%$ of advertisements use celebrities (Elberse \& Verleun 2012), while in East Asian countries, this figure can be as high as 60\% (Yang 2018). In the United Kingdom, research company Statista found that $75 \%$ of advertising agency respondents claimed to use celebrities for their social media advertising ('What roles do celebrities currently play in your marketing strategies' 2016). Statista also found that $98 \%$ of marketers believe that celebrities are highly effective or quite effective in promoting products and brands on social media ('How effective are celebrities as part of the following marketing strategies?' 2016).

Celebrity endorsement has been used very widely in the cosmetic industry in particular, because of the natural link with certain celebrities and beauty products (Marty \& Frempong 2014). 
The cosmetics industry in South Africa contributes an estimated R25.3 billion to the gross domestic product at a retail level (Department of Trade and Industry 2016). Despite economic uncertainties in 2015, there was strong growth in the industry because of the rise in disposable income amongst the black middle classes in South Africa (Department of Trade and Industry 2016). This trend has enhanced sales in many cosmetics products, such as skin care, beauty and facial makeup products, which encourages brand and pricing competition and drives marketers to explore marketing strategies to gain competitive advantage. Cosmetic firms are paying celebrities vast sums of money to endorse their products and gain this competitive advantage (Lord, Petrevu \& Collins 2019). In most countries around the world, marketers tend to use a combination of both local and international celebrities to endorse their products, for example Revlon's most famous local brand ambassador in 2015 was Bonang Matheba, while international star Gwen Stefani has also been a Revlon brand ambassador (adage.com).

\section{Local versus international celebrity endorsers}

A local celebrity is someone who is well known within a particular community (Ndlela \& Chuchu 2016). The local celebrity can either be a local drama actor, local football player or an artist (Wei \& Lu 2013). An international celebrity, on the other hand, is a person who is well known worldwide and can either be a sports person, actor or music artist (Torn 2012). International celebrities, because of their widespread appeal, have been used far more as product endorsers and it has been shown that when popular international celebrities endorse a product, it has a positive impact, but is very costly (Sertoglu, Catli \& Korkmaz 2014). This has potentially led to an underestimation of the impact that local celebrities can have on consumer behaviour (Nyarko et al. 2015). As people aspire to the lifestyle of well known international celebrities, they cannot as easily relate to them as they do with local celebrities (Fleck, Korchia \& Le Roy 2012). Fleck et al. (2012) posited that local celebrities endorsing a local product are more likely to personify the cultural values that local consumers can relate to and there will thus be congruency between the product and the local celebrity that does not exist with international celebrities (Van Der Waldt, Van Loggerenberg \& Wehmeyer 2009). It is also easier for local celebrities to be seen as familiar, similar and likeable, which is an important part of celebrity credibility (Fang \& Jiang 2015).

It is clear therefore that both international and local celebrity endorsers can benefit marketers and help to achieve the longterm goals of profit making, brand recognition and customer loyalty (Fang \& Jiang 2015). Knowing when to use local and when to use international celebrities would be key to a successful and cost-effective marketing campaign.

\section{Problem statement}

The majority of the celebrity endorsement research conducted to date looks at the credibility of the endorser in terms of their attractiveness, trustworthiness and expertise (Jamil \& Rameez ul Hassan 2014; Mikulas \& Svetlik 2016; Ohanian 1990). While much of this research has focused on internationally recognised celebrities, there have also been studies conducted in different countries around the world using local celebrities, which have found similar positive effects on consumer behaviour (Abdurrahaman et al. 2018; Knoll \& Matthes 2017; Ndlela \& Chuchu 2016; Nyarko et al. 2015). Zhang and Zhang (2010) found differences in how Chinese consumers respond to local and international celebrities. So far, however, no studies have been conducted in South Africa to explore the question of whether international or local celebrities have a greater impact on consumer purchase intentions. Local celebrities generally cost far less than their international counterparts and it could be more cost-effective for firms to use local celebrities, but more research is needed to understand if they have a greater or lesser impact on consumers' purchase intentions than their international counterparts.

\section{Objectives of the study}

The primary objective of this study was to examine the influence of the credibility of local and international celebrity endorsement on generation $\mathrm{Y}$ and $\mathrm{Z}$ consumers' intention to purchase cosmetic products.

The secondary objectives were outlined as follows:

- To determine the influence of each credibility dimension (attractiveness, trustworthiness and expertise) on the intention to purchase cosmetic products endorsed by local celebrities.

- To determine the influence of each credibility dimension (attractiveness, trustworthiness and expertise) on the intention to purchase cosmetic products endorsed by international celebrities.

\section{Contributions of the study}

This article contributes on a number of levels. Firstly, on a theoretical level, it adds to the body of knowledge regarding celebrity credibility by comparing local and international celebrity endorsers' impact on purchase intentions. Secondly, the article contributes practically by providing guidelines for marketers about the effective allocation of marketing expenditure towards celebrity endorsement advertising. Furthermore, it provides context-specific knowledge relating to celebrity endorsement and young (generation $\mathrm{Y}$ and $\mathrm{Z}$ ) South African consumers' purchase intentions, an area that has to date not been well explored (Ndlela \& Chuchu 2016).

\section{Conceptual framework: Models of celebrity endorsement}

There are several models that form the basis of the research into celebrity endorsement and its effectiveness. The most well known of these are the source attractiveness, source credibility and endorser match-up models, which relate directly to this study. 


\section{Source attractiveness model}

Attractiveness is a component of McGuire's source valence model (1985). The source valence model defines attractiveness as the outer appearance or rather the beauty that an individual possesses. The model argues that the physical appeal of a celebrity influences the impact an advertisement has on consumers. This, in turn, motivates consumers' intention to purchase the advertised brand (Fang \& Jiang 2015). With this model, the effectiveness of an advertisement also depends on the endorser's similarity, familiarity and likability to the consumers. Similarity refers to some form of recognition or resemblance between the endorser and the consumer. Familiarity is as a result of the respondents or consumers' knowledge of the endorser through exposure. Lastly, likeability is the affection consumers have towards the endorser's physical appeal and behaviour (Sertlogu, Cartli \& Korkmaz 2014). Attractiveness is well recognised as an essential of celebrity endorsement and is explored in more detail below.

\section{Source credibility model}

Early researchers examined celebrity credibility using several dimensions, including trustworthiness, sociability, expertness, authoritativeness, competence and believability. Critics of this early research noted inconsistencies in terms of the constructs and the methodologies used for investigation (Ohanian 1990). Ohanian noted that previous research into both source credibility and source attractiveness used different dimensions to measure overall source credibility. Inasmuch as all these studies were intended to measure one solid construct, there was lack of consistency amongst the researchers as to the characteristics that made up source credibility. Furthermore, while developing construct scales, many of the early researchers did not analyse the reliability and validity of the scales within their models. This resulted in disparities in the literature surrounding source credibility and led to Ohanian developing a reliable credibility scale in 1990 (Pornpitakpan 2003). Ohanian extended the source attractiveness model and included three main qualities in her credibility model, namely expertise, trustworthiness and attractiveness (Moraes et al. 2019). Several studies have since used Ohanian's model as a basis for investigating celebrity credibility (Abdurrahaman et al. 2018; Dwivedi, Johnson \& McDonald 2015; Kang, Choi \& Choi 2019; Lord et al. 2019; Mikulas \& Svetlik 2016; Sertlogu et al. 2014).

Attractiveness refers to the endorser's physical appearance, personality, his or her likeability and similarity to respondents in a targetmarket(Moraes etal.2019). Ohanian operationalised attractiveness as the components of attractive or unattractive, classy or not classy, beautiful or ugly, elegant or plain and sexy or not sexy. Research into source attractiveness has been mixed. Some studies show that attractive endorsers have a positive effect on consumers' attitudes and beliefs towards a product (Abdurrahaman et al. 2018; Lord \& Putrevu 2009; Wang \& Scheinbaum 2017). This is attributed to the halo effect, which states that if an individual or product is rated highly in one dimension, they are also rated highly in other dimensions (Eisend \& Langner 2010). However, there are also studies where this positive effect was not shown to be significant (Bergkvist \& Zhou 2016; Erdogan 1999).

\section{Hypothesis 1 - Celebrity attractiveness:}

$\mathbf{H}^{1 \mathrm{AA}}$ : Celebrity attractiveness has a significantly positive influence on intention to purchase cosmetic products advertised by local celebrities.

$\mathbf{H}^{1 \mathbf{B}}$ : Celebrity attractiveness has a significantly positive influence on intention to purchase cosmetic products advertised by international celebrities.

Trustworthiness is the extent to which consumers perceive the celebrity to be believable and honest, which has an effect on how the brand or product is viewed (Yang 2018). This means that the endorser must be well versed with a product or brand before they persuade consumers to purchase the product. Terms such as 'favourable disposition, acceptance, psychological safety and perceived supportive climate' are referred to as favourable effects of trust (Ohanian 1990). In line with Ohanian's model, the study operationally defines trustworthiness as the measured constructs of dependable or undependable, honest or dishonest, reliable or unreliable, sincere or insincere and trustworthy or untrustworthy. As with the finding on attractiveness, the extant literature on trustworthiness shows mixed findings. Several studies have found that if a consumer trusts an endorser, he or she is more likely to value the products promoted by that endorser (Abdurrahaman et al. 2018; Amos, Holmes \& Strutton 2008; Choi \& Rifon 2012; Dwivedi et al. 2015). However, studies by Ohanian (1990) and Rossiter and Smidts (2012) showed no significant effect of trustworthiness on brand evaluations. Deshpande and Stayman (1994), on the other hand, found that consumers are more likely to trust celebrities who they perceive as culturally or ethnically similar to themselves. Studies have also shown that celebrity trustworthiness is more influential than non-celebrity trustworthiness (Fang \& Jiang 2015), while Speck, Schumann and Thompson (1988) found no significant difference in consumers' evaluation of a product endorsed by non-celebrities versus celebrities. Interestingly, trustworthiness is the one aspect where products or brands are exposed to the risk of damage to their reputations if the celebrity being endorsed engages in socially unacceptable behaviours. Kang et al. (2019) found a significant negative relationship between trustworthiness and brand evaluations where the celebrity involved (Tiger Woods) had been involved in a scandal.

\section{Hypothesis 2 - Celebrity trustworthiness:}

$\mathbf{H}^{2 \mathrm{~A}}$ : Celebrity trustworthiness has a significantly positive influence on intention to purchase cosmetic products advertised by local celebrities.

$\mathbf{H}^{2 \mathrm{~B}}$ : Celebrity trustworthiness has a significantly positive influence on intention to purchase cosmetic products advertised by international celebrities.

Expertise in this context refers to an endorser having the right skills and sufficient knowledge to market a product or brand 
(Radha \& Jija 2013). It also relates to the extent to which a celebrity is seen as an authority figure in a product category (Kang et al. 2019). Ohanian (1990) operationally defined expertise as an endorser's ability to be an expert or nonexpert, experienced or inexperienced, knowledgeable or unknowledgeable, qualified or unqualified and skilled or unskilled. It is believed that the more skilled a celebrity is, the more useful and attractive a celebrity is perceived to be, and so is the brand or product the celebrity is advertising (Choi \& Berger 2010). Rossiter and Smidts (2012) argued that if consumers perceive a celebrity endorser as an expert on a product, he or she will have a positive attitude towards the product and be more likely to buy it. Studies have shown that an endorser's expertise about a product is not important as long as consumers see the endorser as an expert in what they are popularly known for (Keel \& Nataraajan 2012). However, the findings regarding expertise are also mixed, as studies have also been conducted where no significant relationships were found between celebrity endorser expertise and consumer behaviour (Abdurrahaman et al. 2018; Wang \& Scheinbaum 2017).

\section{Hypothesis 3 - Celebrity expertise:}

$\mathbf{H}^{3 \mathrm{~A}}$ : Celebrity expertise has a significantly positive influence on intention to purchase cosmetic products advertised by local celebrities.

$\mathbf{H}^{3 \mathbf{B}}$ : Celebrity expertise has a significantly positive influence on intention to purchase cosmetic products advertised by international celebrities.

\section{Research methodology}

A quantitative research approach was adopted for this study because it aimed to quantify the impact of local and international celebrity credibility on generation $\mathrm{Y}$ and $\mathrm{Z}$ consumers' intention to purchase cosmetics products. Many studies have used quantitative methods with an attempt to gain insights into the concept of celebrity endorsement and its resultant effects (Bergkvist, Hjalmarson \& Magi 2016; Sertlogu et al. 2014).

Data were collected from 237 respondents using convenience sampling, which is a non-probability sampling technique. A survey questionnaire was distributed to female generation Y (born between 1981 and 1996) and generation Z (born between 1997 and 2012) consumers who were first asked to complete an informed consent form. The use of generation $\mathrm{Y}$ and $\mathrm{Z}$ consumers has been well documented in previous studies because they are the generations who are most likely to follow celebrity trends ( Xu \& Pratt 2018). This study delimited the sample to women, as previous research has shown that they make up the majority of the consumers of cosmetics products (Caiola et al. 2018; Fernandes \& Panda 2018).

\section{Questionnaire development}

A questionnaire was designed using print advertisements of both local and international celebrity endorsers of cosmetics products. To identify and select appropriate endorsers for the questionnaire, 40 female generation $\mathrm{Y}$ and $\mathrm{Z}$ consumers were randomly selected and instructed to list all local and international female celebrities they know in $3 \mathrm{~min}$. This pretest survey is similar to that used in other studies on celebrity endorsement such as Ohanian (1990) and Sertlogu et al. (2014). The list of celebrities was then filtered to include only those who endorse cosmetic products or brands and ranked based on the frequency of mention. The top two ranking local celebrities were Connie Ferguson and Bonang Matheba, while Beyonce Knowles and Nicki Minaj were the top ranking international celebrities.

The questionnaire was split into two different sections one for local celebrities and the second for international celebrities. An advertisement depicting each of these two celebrities was then placed in the relevant section (two advertisements for the local celebrity section and two advertisements for the international celebrity section). Beneath both sets of advertisements was a set of questions and respondents were instructed to look at the advertisements and answer the questions rating the credibility of the celebrities depicted.

The questionnaire adapted the intention to purchase scale and Ohanian's credibility scale, both of which have been shown to be reliable and valid in previous studies (Abdurrahaman et al. 2018; Dwivedi et al. 2015; Hung et al. 2011; Jamil \& Rameez ul Hassan 2014; Mikulas \& Svetlik 2016; Sertlogu et al. 2014). The credibility scale used a fiveitem seven-point semantic differential scale for each construct in the scale. That included attractiveness (attractive or unattractive, classy or not classy, beautiful or ugly, elegant or plain and sexy or not sexy), trustworthiness (dependable or undependable, honest or dishonest, reliable or unreliable, sincere or insincere and trustworthy or untrustworthy) and expertise (expert or not expert, experienced or inexperienced, knowledgeable or unknowledgeable, qualified or unqualified and skilled or unskilled). A five-item seven-point Likert scale was also included for each set of celebrity advertisements to measure purchase intention.

\section{Pilot study}

Whenever a self-administered questionnaire is used, it is recommended to run a pilot study before beginning data collection. This is performed to check that the questions work well together, and to see if respondents understand the questions and the instructions (Bryman \& Bell 2015). A pilot study was therefore conducted to ensure that the respondents understood the semantic differential scale as adapted from Ohanian (1990). The pilot study consisted of 30 respondents and showed that the questionnaire was well received. The scales used in the pilot study were tested for reliability by using Cronbach's alpha. Face validity was assessed to determine whether the scales appeared to measure what they intended to measure (Nunnally \& Bernstein 1994). This preliminary analyses did not indicate any problems regarding the reliability and face validity of the measurement instrument. 


\section{Data analysis}

The data were cleaned, prepared and coded in an Excel spreadsheet and then transferred for analysis into the Statistical Package for the Social Sciences (SPSS) version 24. Descriptive statistics were used to summarise and categorise the data and included measures of mean, median and mode, as well as skewness and kurtosis. Inferential statistics were used to give an in-depth understanding of the data by examining the relationships between variables under analysis. The data were examined to ensure that the assumptions of reliability of measurement, homoscedasticity, linearity and normality were met. The Pearson's correlation coefficient was used to ensure that the variables were significantly correlated (Babbie 2016).

The data were then analysed using multiple regression analysis, which calculates the causal effect between independent variables and a dependent variable (Babbie 2016). In the current study, ( $r$ ) was used to calculate the extent to which the independent variables (attractiveness, trustworthiness and expertise) predicted the intention to purchase cosmetic products advertised by either local or international celebrity endorsers. If a strong relationship was observed between the indicators, it meant that there was a clear positive relationship between the independent variables and the dependent variable. $R^{2}$ is regarded as the coefficient of determination and showed how much of the variance in the dependent variable was explained by each independent variable (Hanneman \& Riddle 2011). In the current study, $R^{2}$ was used to calculate the extent to which attractiveness, trustworthiness and expertise explained the variance in consumer's intention to purchase.

\section{Ethical considerations}

The research was conducted following ethical guidelines and participants were asked to sign informed consent forms. These forms highlighted that participation was voluntary and that those who chose not to participate would not be negatively affected in any way. Additionally, participants were made aware that they could stop answering the questions at any point without being penalised. Confidentiality was observed and the participants' identity was not revealed in this research. Ethical clearance was obtained from the University of Fort Hare Research and Ethics Committee (REC-270710-028-RA Level 1, Ethical Clearance Number: VIL141SNYA01, 2017).

\section{Results}

Analysis of the biographical data showed that the majority of the respondents $(82.8 \%)$ were aged 26 years and younger, and $84 \%$ received $\mathrm{R} 5000$ or less as a monthly income. These results were to be expected, given that it was a sample of generation $\mathrm{Y}$ and $\mathrm{Z}$ consumers. The majority of the respondents (96\%) were black African women, reflecting the demographic make-up of the province in which the study was conducted. The analysis also showed a high variance in the data distribution, which was indicated in all of the items as they had a standard deviation above 1 . The skewness and kurtosis results for both local and international celebrity credibility displayed values between -2 and +2 which indicates normality in the distribution of data (George \& Mallery 2010).

Confirmatory factor analysis was used to test the validity of the data, and all sub-constructs were tested separately (attractiveness, trustworthiness and expertise) because of the unidimensionality of the scale. The items on each scale were shown to be valid, and no items were removed. The factor loadings were found to be between the range of 0.539 and 0.918, which are deemed acceptable (Bryman \& Bell 2015). The Cronbach's alpha was used to test the reliability of the data, and all scales in the study were shown to be reliable and valid, with Cronbach's scores ranging from 0.783 to 0.928 which was above the accepted level of 0.7 (Wiid \& Diggines 2014) (see Table 1).

The Pearson correlation coefficient is a standardised measure that explains the strength of the relationship amongst variables (Malhotra 2015). Pearson correlation was used to explain the relationships between the credibility dimensions for local and international celebrities (attractiveness, trustworthiness and expertise) and intention to purchase. Table 2 summarises the correlation scores.

As shown in Table 2, all of the independent variables have statistically significant correlation coefficients with the dependent variable at the 0.005 level of significance.

TABLE 1: Results of validity and reliability testing.

\begin{tabular}{lccc}
\hline Variable & $\begin{array}{c}\text { \% of variance } \\
\text { (AVE): }\end{array}$ & $\begin{array}{c}\text { Factor } \\
\text { loading range } \\
\text { (min and max): }\end{array}$ & $\begin{array}{c}\text { Cronbach's } \\
\text { alpha }\end{array}$ \\
\hline Local celebrity attractiveness & 42.484 & $0.539-0.717$ & 0.783 \\
Local celebrity trustworthiness & 52.572 & $0.547-0.867$ & 0.835 \\
Local celebrity expertise & 57.755 & $0.681-0.858$ & 0.869 \\
Local celebrity intention to purchase & 64.120 & $0.796-0.847$ & 0.899 \\
International celebrity attractiveness & 67.397 & $0.772-0.891$ & 0.911 \\
International celebrity trustworthiness & 63.732 & $0.596-0.893$ & 0.917 \\
$\begin{array}{l}\text { International celebrity expertise } \\
\text { International celebrity intention to }\end{array}$ & 69.279 & $0.756-0.861$ & 0.917 \\
purchase & 72.957 & $0.852-0.918$ & 0.928 \\
\hline
\end{tabular}

TABLE 2: Pearson correlation scores (local and international celebrity credibility). Variable Attractiveness Trustworthiness Expertise Intention to

\begin{tabular}{|c|c|c|c|c|}
\hline & \multirow{2}{*}{1} & \multirow{2}{*}{2} & \multirow{2}{*}{3} & \multirow{2}{*}{$\frac{\text { purchase }}{4}$} \\
\hline & & & & \\
\hline $\begin{array}{l}\text { Local celebrity } \\
\text { attractiveness }\end{array}$ & 1.00 & - & - & - \\
\hline $\begin{array}{l}\text { Local celebrity } \\
\text { trustworthiness }\end{array}$ & $\begin{array}{c}0.474 \\
(p=0.00)\end{array}$ & 1.00 & - & - \\
\hline Local celebrity expertise & $\begin{array}{c}0.436 \\
(p=0.00)\end{array}$ & $\begin{array}{c}0.427 \\
(p=0.00)\end{array}$ & 1.00 & - \\
\hline $\begin{array}{l}\text { Intention to purchase } \\
\text { (local celebrity) }\end{array}$ & $\begin{array}{c}0.394 \\
(p=0.00)\end{array}$ & $\begin{array}{c}0.395 \\
(p=0.00)\end{array}$ & $\begin{array}{c}0.318 \\
(p=0.00)\end{array}$ & 1.00 \\
\hline $\begin{array}{l}\text { International celebrity } \\
\text { attractiveness }\end{array}$ & 1.00 & - & - & - \\
\hline $\begin{array}{l}\text { International celebrity } \\
\text { trustworthiness }\end{array}$ & $\begin{array}{c}0.523 \\
(p=0.00)\end{array}$ & 1.00 & - & - \\
\hline $\begin{array}{l}\text { International celebrity } \\
\text { expertise }\end{array}$ & $\begin{array}{c}0.707 \\
(p=0.00)\end{array}$ & $\begin{array}{c}0.596 \\
(p=0.00)\end{array}$ & 1.00 & - \\
\hline $\begin{array}{l}\text { Intention to purchase } \\
\text { (international celebrities) }\end{array}$ & $\begin{array}{c}0.413 \\
(p=0.00)\end{array}$ & $\begin{array}{c}0.380 \\
(p=0.00)\end{array}$ & $\begin{array}{c}0.474 \\
(p=0.00)\end{array}$ & 1.00 \\
\hline
\end{tabular}




\section{Multiple regression analysis}

The current study used multiple regression to explain the relationship between purchase intention (dependent variable) and celebrity attractiveness, trustworthiness and expertise (independent variables) for both local and international celebrities.

\section{Predictors: (Constant), Total Local Expertise, Total Local Trustworthiness and Total Local Attractiveness}

As summarised in Table 3, the value of the coefficient of determination indicated by the adjusted $R^{2}$ shows that the independent variables (attractiveness, trustworthiness and expertise) in local celebrities explain $21 \%$ of variance in consumer purchase intention (dependant variable). As indicated by $p<0.00$ at $95 \%$ confidence interval and supported by a correlation coefficient of 0.470 , the model can be regarded as significant.

Table 4 shows a positive relationship between local celebrity attractiveness $(r=3.371 ; p \leq 0.01)$ and trustworthiness $(r=3.453 ; p \leq 0.01)$ (at a satisfactory $99 \%$ confidence level), while expertise $(r=1.731 ; p \leq 0.1)$ (at a lower $90 \%$ confidence level) also showed a positive relationship towards the dependent variable 'consumer's purchase intention towards cosmetic products'.

\section{Predictors: (Constant), Total International Expertise, Total International Trustworthiness and Total International Attractiveness}

As presented in Table 5, the value of the adjusted $R^{2}$ was 0.238 , an indication that there was a variation of $23.85 \%$ on consumer purchasing decision which is a result of international celebrities' attractiveness, trustworthiness and expertise. In other words, $23.85 \%$ changes in consumer purchasing decision of cosmetic products are as a result of international celebrity's credibility dimensions. The correlation coefficient of 0.497 posited that there is an adequate overall positive relationship between international celebrity credibility dimensions (attractiveness, trustworthiness and expertise) and intention to purchase.

TABLE 3: Model 1 summary: Local celebrity credibility.

\begin{tabular}{lccccc}
\hline Model & $\boldsymbol{R}$ & $\boldsymbol{R}^{\mathbf{2}}$ & Adjusted $\boldsymbol{R}^{2}$ & Std. error of the estimate & Sig. change \\
\hline 1 & 0.470 & 0.221 & 0.211 & 6.235 & 0.000
\end{tabular}

TABLE 4: Regression coefficients local celebrity credibility.

\begin{tabular}{lccccccc}
\hline Local celebrity credibility & \multicolumn{2}{c}{$\begin{array}{c}\text { Unstandardised } \\
\text { coefficients }\end{array}$} & & $\begin{array}{c}\text { Standardised } \\
\text { coefficients }\end{array}$ & $\boldsymbol{T}$ & Sig \\
\cline { 2 - 3 } & $\boldsymbol{B}$ & Std. error & & Beta & & \\
\hline Constant & 6.794 & 2.253 & & - & 3.015 & 0.030 \\
Local celebrity attractiveness & 0.266 & 0.079 & & 0.231 & 3.371 & $0.001 *$ \\
Local celebrity trustworthiness & 0.255 & 0.074 & & 0.236 & 3.453 & $0.001 *$ \\
Local celebrity expertise & 0.133 & 0.077 & & 0.116 & & 1.731 & 0.085 \\
\hline
\end{tabular}

*, statistically significant at the 0.01 level of significance.

TABLE 5: Model two summary: International celebrity credibility.

\begin{tabular}{lccccc}
\hline Model & $\boldsymbol{R}$ & $\boldsymbol{R}^{2}$ & Adjusted $\boldsymbol{R}^{2}$ & Std. error of the estimate & Sig. change \\
\hline 2 & 0.497 & 0.241 & 0.238 & 6.834 & 0.000
\end{tabular}

The results show positive relationships between the independent variables (attractiveness, trustworthiness and expertise) and the dependent variable (intention to purchase), but only international celebrity expertise was reported as having a significant impact on intention to purchase as the $p$-value was less than 0.05 (see Table 6).

\section{Discussion}

This study was conducted to examine the impact of local and international celebrity credibility on generation $\mathrm{Y}$ and $\mathrm{Z}$ consumers' intention to purchase cosmetics. Results of the multiple regression show the following about the hypotheses (see Table 7).

\section{Hypothesis 1: Attractiveness}

About Hypotheses 1A and 1B, the results of the multiple regression show that local celebrity attractiveness has a significant impact on intention to purchase cosmetic products, but international celebrity attractiveness does not. Both the significant and the non-significant effects are supported in the literature, as previous studies have shown mixed findings. While many studies have demonstrated the significant positive effect of celebrity attractiveness on consumer behaviour (e.g. Abdurrahaman et al. 2018; Eisend \& Langner 2010; Lord \& Putrevu 2009; Wang \& Scheinbaum 2017), there were also studies where no relationship was found (e.g. Bergkvist \& Zhou 2016; Kamins 1990; Ohanian 1990). The positive effect for local celebrities may be as result of the fact that respondents might find them more likeable than international celebrities. This would be in line with the findings of Fang and Jiang

TABLE 6: Regression coefficients: International celebrity credibility.

\begin{tabular}{|c|c|c|c|c|c|}
\hline \multirow[t]{2}{*}{$\begin{array}{l}\text { International celebrity } \\
\text { credibility }\end{array}$} & \multicolumn{2}{|c|}{$\begin{array}{l}\text { Unstandardised } \\
\text { coefficients }\end{array}$} & \multirow{2}{*}{$\begin{array}{c}\begin{array}{c}\text { Standardised } \\
\text { coefficients }\end{array} \\
\text { Beta }\end{array}$} & \multirow[t]{2}{*}{$T$} & \multirow[t]{2}{*}{ Sig } \\
\hline & $B$ & Std. error & & & \\
\hline Constant & 5.069 & 1.857 & - & 2.730 & 0.007 \\
\hline $\begin{array}{l}\text { International celebrity } \\
\text { attractiveness }\end{array}$ & 0.135 & 0.085 & 0.129 & 1.583 & 0.115 \\
\hline $\begin{array}{l}\text { International celebrity } \\
\text { trustworthiness }\end{array}$ & 0.132 & 0.072 & 0.131 & 1.820 & 0.070 \\
\hline International celebrity expertise & 0.315 & 0.090 & 0.304 & 3.510 & $0.001 *$ \\
\hline
\end{tabular}

*, statistically significant at the 0.01 level of significance.

TABLE 7: Summary of hypotheses results.

\begin{tabular}{lcccc}
\hline Statement (alternative hypothesis) & $\begin{array}{c}\text { Beta } \\
\text { coefficients }\end{array}$ & $t$ & $p$ & Decision \\
\hline $\begin{array}{l}\mathrm{H}^{1 \mathrm{~A}} \text { : Local celebrity attractiveness has a } \\
\text { significantly positive influence on } \\
\text { intention to purchase cosmetic products. }\end{array}$ & 0.266 & 3.371 & 0.001 & Accept \\
$\begin{array}{l}\mathrm{H}^{1 \mathrm{~B}} \text { : International celebrity attractiveness } \\
\text { has a significantly positive influence on } \\
\text { intention to purchase cosmetic products. }\end{array}$ & 0.135 & 1.583 & 0.115 & Reject \\
$\begin{array}{l}\mathrm{H}^{2 \mathrm{~A}} \text { : Local celebrity trustworthiness has } \\
\text { a significantly positive influence on } \\
\text { intention to purchase cosmetic products. }\end{array}$ & 0.255 & 3.453 & 0.001 & Accept \\
$\begin{array}{l}\mathrm{H}^{28} \text { : International celebrity trustworthiness } \\
\text { has a significantly positive influence on } \\
\text { intention to purchase cosmetic products. }\end{array}$ & 0.132 & 1.820 & 0.070 & Reject \\
$\begin{array}{l}\mathrm{H}^{\mathrm{BA}} \text { : Local celebrity expertise has a } \\
\text { significantly positive influence on } \\
\text { intention to purchase cosmetic products. }\end{array}$ & 0.133 & 1.731 & 0.085 & Reject \\
$\begin{array}{l}\mathrm{H}^{3 \mathrm{~B}} \text { : International celebrity expertise } \\
\text { has a significantly positive influence on } \\
\text { intention to purchase cosmetic products. }\end{array}$ & 0.315 & 3.510 & 0.001 & Accept \\
\hline
\end{tabular}


(2015) who posited that local celebrities are seen as familiar, similar and likeable, which is an important part of celebrity credibility (Fang \& Jiang 2015).

\section{Hypothesis 2: Trustworthiness}

About Hypotheses 2A and 2B, the results of the multiple regression show that local celebrity trustworthiness has a significant impact on intention to purchase cosmetic products, but international celebrity trustworthiness does not. Once again, these mixed findings are supported in the literature, as several studies have found significant relationships between celebrity trustworthiness and brand evaluations (Amos et al. 2008; Bahram, Zahra \& Zahra 2010; Fleck et al. 2012), while other studies have found no significant effect (Rossiter \& Smidts 2012; Ohanian 1990).

In terms of trustworthiness, it is notable that in the cosmetic industry, many facial and skin products can have side effects when used incorrectly. Therefore, consumers require an endorser that they can trust. As noted with celebrity attractiveness, it may be that local celebrities represent local standards consumers are familiar with and this may mean that consumers more easily trust local celebrities (Bahram et al. 2010). Ad hoc comments noted during the pilot study revealed that consumers found it more difficult to rate the honesty and trustworthiness of international celebrities than local celebrities, as they are unfamiliar and different.

\section{Hypothesis 3: Expertise}

About Hypotheses $3 \mathrm{~A}$ and $3 \mathrm{~B}$, the results of the multiple regression show that international celebrity expertise has a significant impact on intention to purchase cosmetic products, but local celebrity expertise does not. International celebrities are globally perceived as experts in what they do; therefore, whenever they endorse a product, even if they have no relevant expertise, their expertise in everything else adds to a general perceived level of expertise (Eisend \& Langner 2010). It may also be relevant that the South African cosmetics industry is dominated by Revlon which is an international company (Department of Trade and Industry report 2016), and this may lead consumers to attribute more weight to the expertise of international celebrities.

\section{Discussion regarding the primary objective}

The primary objective of the study was to examine the influence of the credibility of local and international celebrity endorsement on generation $\mathrm{Y}$ and $\mathrm{Z}$ consumers' intention to purchase cosmetic products. The results showed that, overall, these young consumers perceive local and international celebrities differently. Local celebrities who are seen as trustworthy and attractive may have more impact than international celebrities with similar traits, while international celebrities with expertise may have more impact than local celebrities with expertise. The study has shown that local South African celebrities have a greater overall impact on
South African generation $\mathrm{Y}$ and $\mathrm{Z}$ consumers in terms of their intentions to purchase cosmetics products. This may be as a result of the 'pertinent effect' whereby physical and psychological nearness, as well as relevance to a local celebrity, makes consumers relate to them and develop an interest in what they do (Bahram et al. 2010). South African celebrities, more so than international celebrities, are seen as real people, and they influence local consumers' purchase behaviour. It is also possible that because of the impact of social media, generation $\mathrm{Y}$ and $\mathrm{Z}$ are more likely to have local role models that they can more easily relate to and emulate (Ndlela \& Chuchu 2016).

The mixed findings presented here and in previous studies highlight the complex nature of this relationship and suggest that there may be moderating variables, which have not been previously identified (Bergkvist \& Zhou 2016). Given the nature of these findings, it is possible that celebrity nationality may be a moderating variable.

\section{Managerial implications}

The study suggests that South African marketers should continue using celebrities to endorse products aimed at the generation $\mathrm{Y}$ and $\mathrm{Z}$ target markets, because celebrity endorsement does indeed have a significant effect on the purchase intention of these consumers.

Overall, local celebrities showed a bigger impact on generation $\mathrm{Y}$ and $\mathrm{Z}$ consumers' purchase intentions than international celebrities, suggesting that marketers of cosmetics should give preference to local celebrities when endorsing products. This would, in turn, have a positive impact on the company's advertising budget and return on investment as local celebrities are usually cheaper.

Marketers who are targeting these consumers should focus on local celebrities who are attractive and trustworthy and should avoid celebrities with a damaged reputation.

Marketers of cosmetics could consider limiting the use of international celebrities to products which require a level of expertise and knowledge. It may be useful to consider using international celebrities at very strategic points in the product life cycle. For example, at the introductory phase when it is important to convey specific information about the product, it may be more beneficial to use international celebrities. When considering expertise, marketers should engage international celebrities who can be seen as authorities in the field, as this will have the biggest impact.

\section{Limitations of the study}

This study was conducted with a sample of generation $\mathrm{Y}$ and $\mathrm{Z}$ consumers in one region and focused specifically on celebrity endorsement in the cosmetics industry. The findings are therefore not easily generalisable to celebrity endorsement of other products or services. The study was 
conducted with female consumers only, so findings cannot be generalised to male consumers.

\section{Future research}

Future research would be needed to see if these results would be relevant to the endorsement of other products and to see if older consumers respond in the same way. Further research should be conducted to directly examine the nationality of the celebrity as a moderating variable. Other studies could also look at whether men respond in the same way to local and international celebrities.

\section{Conclusion}

The impact of local and international celebrity credibility on generation $\mathrm{Y}$ and $\mathrm{Z}$ consumers' purchase intentions was investigated, and the relationships between the various constructs were analysed. Mixed findings pointed to the complex nature of the relationships, suggesting that young consumers do indeed respond differently to local and international celebrities, and the celebrity's nationality may be a moderating variable in the relationship, although further research would be needed to confirm this. Marketers should consider using local and international celebrities for different purposes when advertising and endorsing their brands.

\section{Acknowledgements Competing interests}

The authors have declared that no competing interest exists.

\section{Authors' contributions}

All authors have contributed equally to this work.

\section{Funding}

This research received no specific grant from any funding agency in the public, commercial or not-for-profit sectors.

\section{Data availability statement}

Data sharing is not applicable to this article as no new data were created or analysed in this study.

\section{Disclaimer}

The views and opinions expressed in this article are those of the authors and do not necessarily reflect the official policy or position of any affiliated agency of the authors.

\section{References}

Abdurrahaman, D.T., Owusu, A., Soladoye, B.A. \& Kalimuthu, K.R., 2018, 'Celebritybrand endorsement: A study on its impacts on generation y-ers in Nigeria', Asian Journal of Scientific Research 11(3), 415-427. https://doi.org/10.3923/ajsr.2018. Journal of

Amos, C., Holmes, G. \& Strutton, D., 2008, 'Exploring the relationship between celebrity endorser effects and advertising effectiveness', International Journal of Advertising 27(2), 209-234. https://doi.org/10.1080/02650487.2008.1107 3052
Babbie, E.R., 2016, The basics of social research, 7th edn., Cengage learning, Boston, MA.

Bahram, R., Zahra, S. \& Zahra, M., 2010, 'Celebrity endorser influence on attitude toward advertisements and brands', European Journal of Social Sciences 13(3), 399-407.

Bergkvist, L., Hjalmarson, H. \& Magi, A.W., 2016, 'A new model of how celebrity endorsements work: Attitude toward the endorsement as a mediator of celebrity source and endorsement effects', International Journal of Advertising 35(2), 171-184. https://doi.org/10.1080/02650487.2015.1024384

Bergkvist, L. \& Zhou, K.Q., 2016, 'Celebrity endorsements: A literature review and research agenda', International Journal of Advertising 35(4), 642-663. https://doi. org/10.1080/02650487.2015.1137537

Bryman, A. \& Bell, E., 2015, Business research methods, 4th edn., Oxford University, Cambridge.

Caiola, S., Palleschi, L., Draisci, R. \& Mancinelli, R., 2018, 'Cosmetics, chemical exposure and gender differences', Italian Journal of Gender-Specific Medicine 4(1), 21-26.

Choi, C.J. \& Berger, R., 2010, 'Ethics of celebrities and their increasing influence in 21st century society', Journal of Business Ethics 91(3), 313-318. https://doi.org/ 10.1007/s10551-009-0090-4

Choi, S.M. \& Rifon, N.J., 2012, 'It is a match: The impact of congruence between celebrity image and consumer ideal self on endorsement effectiveness', Psychology and Marketing Journal 29(2), 639-650. https://doi.org/10.1002/mar.20550

Deshpande, R. \& Stayman, D.M., 1994, 'A tale of two cities: Distinctiveness theory and advertising effectiveness', Journal of Marketing Research 31(1), 57-64. https:// doi.org/10.1177/002224379403100105

Department of Trade and Industry, 2016, National directory of small business support programmes, The DTI, Pretoria, South Africa.

Dwivedi, A., Johnson, L.W. \& McDonald, R.E., 2015, 'Celebrity endorsement, self brand connection and consumer-based brand equity', Journal of Product \& Brand Management 24(5), 449-461. https://doi.org/10.1108/JPBM-10-2014-0722

Eisend, M. \& Langner, T., 2010, 'Immediate and delayed advertising effects of celebrity endorsers attacriveness and expertise', International Journal of Advertising 29(4), 527-546. https://doi.org/10.2501/S0265048710201336

Elberse, A. \& Verleun, J., 2012, 'The economic value of celebrity endorsements', Journal of Advertising Research 52(2), 149-165. https://doi.org/10.2501/JAR-52 2-149-165

Erdogan, Z., 1999, 'Celebrity endorsement: A literature review', Journal of Marketing Management 15(4), 291-314. https://doi.org/10.1362/026725799784870379

Fang, L. \& Jiang, Y., 2015, 'Persuasiveness of celebrity endorsed advertising and a new model for celebrity endorser selection', Journal of Asian Business Strategy 5(8), 13-42.

Fernandes, S.F. \& Panda, R., 2018, 'Social reference group influence on women buying behaviour: A review', Journal of Commerce \& Management Thought 9(2a), 273-291. https://doi.org/10.5958/0976-478X.2018.00019.8

Fleck, N., Korchia, M. \& Le Roy, I., 2012, 'Celebrities in advertising: Looking for congruence or likability?', Psychology \& Marketing 29(9), 651-662. https://doi. org/10.1002/mar.20551

George, D. \& Mallery, P., 2010, SPSS for Windows step by step. A simple study guide and reference, 10th edn., Pearson, Boston, MA.

Hanneman, R.A. \& Riddle, M., 2011, 'Concepts and measures for basic network analysis', in J. Scott \& P.J. Carrington (eds.), The Sage handbook of social network analysis, pp. 340-369. Sage, Thousand Oaks, CA.

Statista Research Department, 2016, How effective are celebrities as part of the following marketing strategies?, viewed 30 June 2016, from https://www. statista.com/statistics/711291/celebrity-marketing-effectiveness-in-the-uk/.

Hung, K., Chen, A.H., Peng, N., Hackley, C., Tiwsakul, R.A. \& Chou, C., 2011 'Antecedents of luxury brand purchase intention', Journal of Product and Brand Management 20(6), 457-467. https://doi.org/10.1108/10610421111166603

Jamil, R.A. \& Rameez ul Hassan, S., 2014, 'Influence of celebrity endorsement on consumer purchase intention for existing products: A comparative study', Journa of Management Information 4(1), 1-23. https://doi.org/10.31580/jmi.v4i1.18

Jargalsaikhan, T. \& Korotina, A., 2016, Attitudes towards Instagram micro-celebrities and their influence on consumers' purchasing decisions, Jonkoping University, Sweden.

Kamins, M.A., 1990, 'An investigation into the "match-up" hypothesis in celebrity advertising: When beauty may be only skin deep', Journal of Advertising 19(March), 4-13. https://doi.org/10.1080/00913367.1990.10673175

Kang, M.Y., Choi, Y. \& Choi, J., 2019, 'The effect of celebrity endorsement on sustainable firm value: Evidence from the Korean telecommunications industry', Internationa Journal of Advertising 38(4), 563-576. https://doi.org/10.1080/02650487.2019.1 601910

Keel, A. \& Nataraajan, R., 2012, 'Celebrity endorsements and beyond: New avenues for celebrity branding', Psychology \& Marketing 29(9), 690-703. https://doi. org/10.1002/mar.20555

Knoll, J. \& Matthes, J., 2017, 'The effectiveness of celebrity endorsements: A metaanalysis', Journal of the Academy of Marketing Science 45(1), 55-75. https://doi. org/10.1007/s11747-016-0503-8

Lord, K.R. \& Putrevu, S., 2009, 'Informational and transformational responses to celebrity endorsements', Journal of Current Issues \& Research in Advertising 31(1), 1-13, Spring. https://doi.org/10.1080/10641734.2009.10505253

Lord, K.R., Putrevu, S. \& Collins, A.F., 2019, 'Ethnic influences on attractiveness and trustworthiness perceptions of celebrity endorsers', International Journal of Advertising 38(3), 489-505. https://doi.org/10.1080/02650487.2018.1548196 
Malhotra, N.K., 2015, Basic marketing research: Pearson new international, 4th edn., Pearson, New Delhi.

Marty, E.M. \& Frempong, J., 2014, 'The impact of celebrities' endorsement on brand positioning on mobile telecommunication users in the Eastern Region of Ghana', International Journal of Education and Research 2(7), 201-248.

McCracken, G., 1989, 'Who is the celebrity endorser? Cultural foundations of the endorsement process', Journal of Consumer Research 16(3), 310-321. https://doi. org/10.1086/209217

McGuire, W.J., 1985, 'Attitudes and attitude change', in G. Lindzey \& E. Aronson (eds.), Handbook of social psychology, 3rd edn., pp. 233-346, Random House, New York.

Moraes, M., Gountas, J., Gountas, S. \& Sharma, P., 2019, 'Celebrity influences on consumer decision making: New insights and research directions', Journal of Marketing Management, 35(13-14), 1159-1192. https://doi.org/10.1080/02672 57X.2019.1632373

Ndlela, T. \& Chuchu, T., 2016 'Celebrity endorsement advertising: Brand awareness, brand recall, brand loyalty as antecedence of South African young consumer's purchase behaviour', Journal of Economics and Behavioural Studies 8(2), 79-90.

Nunnally, J.C. \& Bernstein, I.H., 1994, Psychometric theory, McGrawHill, New York.

Nyarko, I.K., Asimah, V., Agbemava, E. \& Tsetse, E.K., 2015, 'The influence of celebrity endorsement on the buying behaviour of the Ghanaian youth: A study of fan milk Ghana ads', International Journal of Business and Management Review 3(11), 1-16.

Ohanian, R., 1990, 'Construction and validation of a scale to measure celebrity endorser's perceived expertise, trustworthiness, and attractiveness', Journal of Advertising 19(3), 39-52. https://doi.org/10.1080/00913367.1990.10673191

Pornpitakpan, C., 2003, 'The effect of celebrity endosers perceived credibilty on product purchase intention', Journal of International Consumer Marketing 16(2), 55-74. https://doi.org/10.1300/J046v16n02_04

Radha, G. \& Jija, P., 2013, 'Influence of celebrity endorsment on the consumer's purchase decision', International Journal of Scientific and Research Publications $3(11), 2250-3153$.

Rossiter, J.R. \& Smidts, A., 2012, 'Print advertising: Celebrity presenters', Journal of Business Research 65(7), 874-879. https://doi.org/10.1016/j.jbusres.2011.01.010
Sertoglu, A.E., Catli, O. \& Korkmaz, S., 2014, 'Examining the effect of endorser credibilty on the consumer's buying intentions: An empirical study in Turkey', International Review of Management and Marketing 4(1), 66-77.

Speck, P.S., Schumann, D.W. \& Thompson, C., 1988, 'Celebrity endorsements-scripts, schema and roles: Theoretical framework and preliminary tests', Advances in Consumer Research 15, 69-76.

Torn, F., 2012, 'Revisiting the match-up hypothesis: Effects of brand-incongruent celebrity endorsements', Journal of Current Issues \& Research in Advertising 33(1), 42-49. https://doi.org/10.1080/10641734.2012.675557

Van der Waldt, D.L.R., Van Loggerenberg, M. \& Wehmeyer, L., 2009, 'Celebrity endorsements versus created spokespersons in advertising: A survey among students', South African Journal of Economic and Management Sciences 12(1), 100-114. https://doi.org/10.4102/sajems.v12i1.263

Wei, P.S. \& Lu, H.P., 2013, 'An examination of the celebrity endorsements and online customer reviews influence female consumer's shopping behaviour', Computers in Human Behaviour Journal 29(1), 193-201. https://doi.org/10.1016/j.chb. 2012.08.005

What roles do celebrities currently play in your marketing strategies?, viewed 30 June 2016, from https://www.statista.com/statistics/711335/celebrity-roles-in2016, from https://www.statist
marketing-strategies-in-the-uk/.

Wiid, J. \& Diggines, C., 2014, Marketing research, 2nd edn., Juta and Company, Cape Town.

Winterich, K.P., Gangwar, M. \& Grewal, R., 2018, 'When celebrities count: Power distance beliefs and celebrity endorsements', Journal of Marketing 82(3), 70-86. https://doi.org/10.1509/jm.16.0169

Xu, X. \& Pratt, S., 2018, 'Social media influencers as endorsers to promote trave destinations: An application of self-congruence theory to the Chinese generation $Y^{\prime}$, Journal of Travel \& Tourism Marketing 35(7), 958-972. https://doi.org/10.108 $0 / 10548408.2018 .1468851$

Yang, W., 2018, 'Star power: The evolution of celebrity endorsement research', International Journal of Contemporary Hospitality Management 30(1), 389-415. https://doi.org/10.1108/IJCHM-09-2016-0543

Zhang, H.-X. \& Zhang, Y, 2010, 'Is nationality important? A new perspective on the relationship between celebrity endorsement and advertising effects', Acto relationship between celebrity endorsement and advertising effects', Acta
Psychologica Sinica 42(2), 304-316. https://doi.org/10.3724/SP.J.1041.2010.00304 